\title{
A Widening Gap Between Official Teacher Training and Professional Life in Norway
}

\author{
Eli Smeplass $^{1} \mathbb{D} \cdot$ Håkon Leiulfsrud $^{2}$ (D)
}

Received: 7 September 2020 / Accepted: 27 October 2021 / Published online: 8 November 2021

(c) The Author(s) 2021

\begin{abstract}
A sociological case study of Norwegian teachers reveals how teacher education reforms have inadequate definitions of teacher competence. Legislators, officials and the media continue to uphold the image of a school system and teaching profession in crisis in several OECD countries. For the Nordic welfare states, education is a public good. Mediocre results in international comparisons cause public debate regarding the quality of the educational system. This has led to a devaluation of teachers and teacher education. The aim of this article is to analyze and discuss how teacher education is valued and converted by Norwegian teachers. Interviews and written accounts from novice teachers and persons with teacher training working outside of the school environment suggest an alternative narrative in which teachers' competences are in high demand. The results and discussion reveal a more nuanced way to view teachers' expertise as an asset in a multitude of careers.
\end{abstract}

Keywords Teacher education $\cdot$ Reform $\cdot$ Competence $\cdot$ Neo-institutionalism · Teacher turnover

\section{Introduction}

This article reports on a qualitative sociological study of the Norwegian teacher education in a changing institutional landscape (Smeplass, 2018). School systems and teacher training are undergoing revisions in several Organization for Economic Co-operation and Development (OECD) countries (Bieber \& Martens, 2011).

$\triangle$ Eli Smeplass

eli.smeplass@ntnu.no

Håkon Leiulfsrud

hakon.leiulfsrud@ntnu.no

1 Department of Teacher Education, Norwegian University of Science and Technology, Trondheim, Norway

2 Department of Sociology and Political Science, Norwegian University of Science and Technology, Trondheim, Norway 
Consequently, we observe numerous attempts to devaluate the overall quality of teacher training. However, we also observe a growing number of reforms aimed at improving teacher education (Advisory Panel for Teacher Education, 2020). Norway is hardly unique in this respect, but the country is of general interest, as it is a small nation that is eager to follow what is generally regarded as "best practice" by the OECD (Nusche et al., 2011). In Norway, as in many other countries, more attention is directed towards teacher education in the quest to improve education (Barton et al., 1994). A North American influence is dominating international research on teachers' effectiveness and the content of teacher education (Cochran-Smith, 2013), although the attached systems of evaluation represent a narrow view of teachers' qualities and purpose (Holloway, 2018). A strong public economy and a political willingness to do what it takes to address the problem have also resulted in a large number of measures being put in place since the mid-1990s (Ministry of Local Government \& Modernization Norway, 2016; Johnsen, 2005; Lindblad et al., 2018). In the Norwegian case, new national teacher education frameworks have been implemented to improve teacher quality (Ministry of Education and Research Norway, 2010, 2015b), ensure the national standardization of education (Ministry of Education \& Research Norway, 2014) and increase the requirements for teacher competences (Ministry of Education and Research Norway, 2016a). The current changes are, in most cases, legitimized with arguments pointing to OECD standards (Ministry of Education Norway, 2016b) and established notions of how educational policy should look to common benchmarks in order to improve educational quality. We argue that this intensified search for output improvement causes Norwegian policymakers to overlook strengths in the current school organization as well as professional qualities of teachers.

As is expected when the emphasis is placed on the actors, rather than the organizations involved, the public discourse tends to reduce the issue to being "a teacher problem." Policymakers assume that teacher competence can be governed and regulated with more control and monitoring of teaching as a profession. Teachers and their interest organizations are losing ground in this discussion, and the list of consultative organizations in educational policy is increasing (Ministry of Education \& Research Norway, 2015a), suggesting that the central actors in educational policy are no longer the teachers and their associations. As we illustrate, the current critiques of teacher skills and credentials in Norway are based on a narrow and instrumentally based understanding of the teaching profession that overlooks important aspects of the social value of the profession and the more unofficial aspects of the teacher role.

Our aim is to analyze and discuss the value of teacher training as perceived by Norwegian teacher students and fully qualified teachers after graduation. Our analysis is based on qualitative data material with 51 informants from two groups: teacher students during and after their studies and teachers working outside the education sector. To situate teacher training in Norway, we give a brief introduction based on available statistics and white papers before we describe the methods and data material used to substantiate the conclusions made. The theoretical framework is neoinstitutionalism and an organizational approach with a focus on individuals' adaptation and interpretation of formal structure and institutionalized myth (Meyer \& 
Rowan, 1977). Our analysis presents three alternative empirical cases that illustrate different, yet important, narratives of the value of teacher education. These analytical cases are (i) teacher students' expectations and frustrations, (ii) novice teachers' narratives from their first year as educators and (iii) teachers working outside of the school system describing their relations to the labor market. We conclude that professional qualities obtained during teacher studies include abilities in pedagogical values, human relations, communication and leadership skills. These skills are in high demand in labor markets beyond school-based education, illustrating that educational reforms in recent years might widen the gap between official teacher training and professional life in Norway.

\section{Regulation and Certification of Teachers in Society}

The professional teacher is a social construct (Berger \& Luckman, 1967) that is produced and reproduced in language and through and within various systems of knowledge. This construct is also expressed through official frameworks stating what good teachers are, what they are expected to accomplish and, increasingly predominantly, how they should or should not do their work (Ministry of Education and Research Norway, 2009; OECD, 2012; Utdanningsforbundet, 2018). One of the most significant changes in Norwegian teacher education in recent years is the change of the national framework plan for teachers. Reforms have shifted from the general teacher reform in 1999 to the elementary school teacher reform in 2010 to a master reform in 2017 (Advisory Panel for Teacher Education, 2020). In summary, these changes represent a move towards a more academic teacher-training, believed to strengthen teachers' knowledge by focusing on their formal subject competence. Meanwhile, the state government has interests invested in the profession on a structural level, ensuring access, production and control of professional personnel. The formal teacher certification is the teacher diploma, an official document regulated by national law. This evidence of approval constitutes an institutionalized form of cultural capital (Noordegraaf \& Schinkel, 2011) that allows access to hold a professional position but gives no obligation to do so. An institutionalized system of qualification creates a dichotomy between those who are unqualified and those who are trained and licensed to engage in a specific profession, such as a teacher. From the government's perspective, investments in teacher education ensures a satisfactory number of professionals at any given time (Roksvaag \& Texmon, 2012), which helps to avoid future shortages of education personnel and may also give people with teacher training a stronger market value and negotiation power.

\section{Statistics on Teacher Turnover in Norway}

In Norway, 78,744 elementary school teachers worked as teachers, while 448 were registered as unemployed in 2018 (Statistics Norway, 2017, 2021; Nav, 2021). The unemployment rate for teachers was only $0.57 \%$. In addition, 26,300 high school teachers worked in the educational sector, while 245 were registered as unemployed, 
(i.e., an unemployment rate of $0.93 \%$ ). The overall national unemployment level at the same time was $2.4 \%$, demonstrating that persons with teacher training are less likely to be unemployed than the general population. Some researchers have reported that $67 \%$ of all qualified teachers work in the education sector (Köber et al., 2005); others claim that $72.2 \%$ of novice teachers work in schools (GNIST, 2016). This illustrates that even though most of the people who earn their teaching degree tend to work as teachers in schools, many also find work elsewhere. This outcome may be interpreted in several ways. The Norwegian teacher association argues that teachers' working conditions are deteriorating (Lund et al., 2017). The statistics available from the Norwegian Ministry of Education, however, show that only $10 \%$ of those who have worked as qualified teachers leave for a job elsewhere (Ministry of Education \& Research Norway, 2017). The teacher turnover statistics can be used to argue for several different policy interventions, depending on what type of problem is being addressed. Nonetheless, from these controversies, it can be seen that (a) people with teacher training in Norway are better off than those in most other professions in terms of employment chances, including those who work outside of the education sector; and (b) even though teacher education is understood primarily as a means to produce qualified teachers for the school system, a substantial number follow other career paths. As a consequence, in this paper we are less interested in push and pull effects and policy arguments and more interested in how teacher professionalization is created, understood and used in various contexts.

\section{Theoretical Approach}

The study is theoretically informed by sociological perspectives and an organizational focus with a focus on individuals' adaptations and interpretations of formal structures and institutionalized myths (Brunsson, 1989, 2006; Meyer \& Rowan, 1977, 2006). In this framework, we consider how organizations act and behave in accordance with external expectations to gain legitimacy and to adjust to institutionalized expectations in the environment by norms being formally represented. We also consider how the teacher educational organizations adaptation has few consequences as organizations tend to decouple their practices and core activities from formal representation. To maintain official conformity, teacher education organizations may buffer their formal structures from the reforms by becoming loosely coupled, placing gaps between their formal structures and actual activities (Meyer \& Rowan, 1977, p. 341). By decoupling from an instrumental perspective of teachers' competences, they can continue to uphold professional norms and pedagogical values, without risking producing teachers who are only interested in subject matters. This approach is particularly well-suited to study the relationship between official policies and social practices, as teacher competence is narrowly defined in the national framework and government plans. 
Table 1 Overview of data

\begin{tabular}{llll}
\hline Informant type & $\begin{array}{l}\text { Number of } \\
\text { informants }\end{array}$ & Gender distribution & Type of data \\
\hline $\begin{array}{c}\text { Teacher stu- } \\
\text { dents }\end{array}$ & $32 *$ & $\begin{array}{l}5 \text { men } \\
27 \text { women }\end{array}$ & $\begin{array}{l}\text { First contact: } 11 \text { focus group interviews with } 32 \\
\text { teacher students } \\
\text { Second contact: } 27 \text { written accounts at the end of } \\
\text { the final semester } \\
\text { Third contact: Four interviews, } 26 \text { written accounts } \\
\text { and questionnaires }\end{array}$ \\
& & & 11 written accounts \\
& & 8 interviews \\
Teachers in & $19 * *$ & 11 women &
\end{tabular}

${ }^{a}$ This includes eight primary school teachers, 12 school teachers, six informants from the master's program in education at a university college and six informants from the high school teacher program at a university

${ }^{\mathrm{b}}$ These informants attended various teacher education programs and graduated between 1972 and 2013

\section{Methodology and Empirical Data}

To extend the theoretical vocabulary of how actors act and think, we also rely on a more explorative and heuristic approach of theorizing (Swedberg, 2012). Theorizing is a reflexive way of opening up the relation between empirical data and theoretical positions and can be used to question dominant perspectives, such as a problematic teacher education (Smeplass, 2018). The study was designed with the aim of exploring alternative understandings of the teaching profession and teacher education and is based on a multi-methodological qualitative approach. The data material for this analysis was collected over a period of 2 years, from 2015 to 2017. In this article, we are especially interested in transitions between education programs and employment in schools and in alternative professional careers. The empirical data consist of accounts from 51 strategically recruited informants, presented in Table 1. Their experiences were documented through 11 focus groups, eight individual interviews, 43 written accounts and 26 questionnaires. The informants represent two different categories. The first category includes 32 teacher students, who were followed from their education into the first year of their professional work life. These participants were first interviewed in focus groups, and two written follow-up accounts were subsequently gathered in addition to a qualitative and quantitative questionnaire. The second category of informants includes 19 persons who have a teaching degree but are employed outside the education sector. Eight of these participants were interviewed, and 11 provided written accounts.

Our data is analyzed by thematic analysis (Braun \& Clarke, 2006), exploring a broader range of topics and roles. The questionnaires provided us with interesting descriptive information about the novice teachers but were mainly analyzed as a supplement to the qualitative material. The interview guides were adjusted to the informants' current situation as students, teachers or those in another line of work. The focus groups enabled us to engage with teacher students in discussions about their various strengths and insecurities. The individual follow-up interviews 
and accounts gave us access to their personal thoughts and experiences as novice teachers. A codebook was developed and reshaped after several rounds of analysis (DeCuir et al., 2011; Saldaña, 2015), and all the data material was carefully analyzed and systematized for this study. Teachers outside the education sector were encouraged to reflect upon their career choices and possibilities. They were also asked how their educational background was useful in their current work environment. All interviews were conducted in Norwegian, carefully transcribed and anonymized. Ethical considerations were done in line with national and international standards to ensure our informants safety and integrity. All quotations were translated into English by the first author after the analysis was finished. We find that this combination of data provides us with nuanced material for understanding the experience of entering the labor market after obtaining a teaching degree, presented in the following three sections.

\section{Analysis}

\section{Teacher Students' Expectations and Frustrations}

Teacher students who had reached the end of their studies were asked to discuss their overall experience with their education and how well it prepared them for entering the professional environment. A major pattern in all the focus group interviews with the teacher students was uncertainty, which was expressed as both a concern about having inadequate skills and a lack of professional confidence as future teachers:

I definitely do not feel prepared to be a teacher. I have talked to many others who feel the same. I have been working as a substitute teacher the past year, and through this experience, I have found many gaps in my competence that I feel the education should have better prepared me for. I now find it much easier to talk about what I lack as a teacher rather than what I can do. (Sara)

Sara is at the end of her training to become a middle school teacher. In her narrative (and those of the other informants in this group interview), she criticized her training as having insufficiently prepared her for work as a teacher. The narratives of uncertainty appeared again in several of the individual interviews and in the written accounts. Teacher students' insecurities illustrate how the translation of competence in a complex field of practice diverges from the prototype of "a good teacher" presented in the official documents (Ministry of Education \& Research Norway, 2014). Several of our groups discussed confusion regarding the formal competences they were expected to have in terms of credit points and subjectspecific knowledge at the expense of a realistic view of the school as a workplace:

Ann: The relationship between our college and the practice school hasn't been very good, I think. Because the follow up...

Tori: Yes, I think it was quite poor, actually. The supervising teachers received vague and insecure evaluations about our teacher training. 
Ann: My practice school last year was kind of in that situation. The teachers meet [with the college] every year before the students' practice period, and she [the supervisor] said that she didn't get ANYTHING out of that meeting. What they discussed had nothing to do with the reality.

Mary: I remember how I was dissatisfied with the practice reports. There were many goals included that supervisors actually didn't have any basis for assessing us in. So, they were forced to say, "Sure, you've achieved this goal." There are many strange goals.

The students felt that attempts to control and standardize their practical training were meaningless and superficial. The "strangeness" of the practice goals reveals a gap between the theoretical world of teaching and the everyday tasks and situations in schools, which is difficult to regulate.

Rather than feeling underqualified in their teaching subjects, which is the major focal point of the latest teacher educational reforms in Norway, the teacher students explained that they lacked practical training and felt that they needed more school practice. The questionnaires reveal that $90 \%$ of the teacher students were unofficially working as substitute teachers during their studies. This extra work may, in addition to income, be a coping strategy to ensure that they gain more practice than the education alone would provide. It also illustrates how teacher students have an especially strong interest in the practical aspects of the teacher role and profession. Several participants emphasized how they felt that the theoretical shift within teacher education has created uncertainty in the transition into the labor market. Maria, who is a primary school teacher, explained how, after experiencing practice in the field, she would rather focus on social aspects of being a teacher:

The most important thing I have learned about being a teacher is how important relations are for well-being and learning, for both teachers and students. Earlier, I had the impression that subject matter was at the core of our practice, but this view changed rather rapidly after my first practical experiences. The degree to which children are much more eager to learn when our relations are good is immense.

This quote illustrates that although policymakers are preoccupied with welldefined goals and specifications in the design of teacher education reforms, professional ideals appear to be more ambiguous and diverse. Several respondents said that they needed more didactical training; yet, others were more concerned about how to handle relations with children and parents. Strikingly few mentioned theory, pedagogy or subjects as matters of great concern. In sum, the analysis shows that the teacher students tend to undervalue their competence as professional teachers as well as their educational credentials. 


\section{Translated Teacher Competence}

An important part of this study was comparing the students' expectations before and after their entry into the school as fully qualified professionals. Those working as teachers were asked to reflect upon their work experiences and report on how their teacher education had prepared them for their new roles a year after finishing their degree. This group included 24 persons working as teachers in 24 schools across Norway. After their first year as professional teachers, a majority, three-quarters of our informants, reported that they felt qualified to work as teachers. Two informants regarded themselves as over-qualified. This finding represents a dramatic change from the insecurities observed from persons a year earlier in their careers. Whether this was due to teacher training as such or to personal attributes is an open question, but it is interesting to observe that several informants tended to emphasize their personal abilities:

I still feel that I spent four years obtaining my degree without receiving the skills I need. The education focuses on didactics, but there are so many other things besides didactics that you need to be a good teacher. As a teacher, you have to be knowledgeable in your subjects, have didactical skills, be able to communicate with children and teenagers, be able to create good relations, stay calm in stressful situations, relate to parents, assess if children need extraordinary measures, give useful feedback, etcetera. The teacher education only prepares you for a small fraction of what to expect when you start working. (Birgitte, middle school teacher)

Although the views expressed by Birgitte were shared by several of the respondents, we also observed that most of the novice teachers in our study had to teach subjects outside of their formal qualifications. This finding suggests that newly trained teachers have to be especially adaptable in transitioning to professional life, which entails utilizing more of the generic skills associated with being a teacher. Agnes, a high school teacher, illustrates this well:

I have experienced that the teacher education, with its focus on pedagogical and human competence, has given plenty of useful knowledge translatable into other jobs. I expected that the teacher education would be more directed towards the profession, but all I have learned, in my subject specialization, pedagogics and practice, have proven relevant on a more general level.

Overall, we found that the teachers reported a more positive attitude towards their own competence after entering the labor force. This finding illustrates how teachers' professionalism and competency can be regarded as a more complex phenomenon than what was reflected in the official framework for teacher education.

Several stated that more generic skills, such as their communication skills or social abilities, are important qualities. In response to the question of which qualities were most important during her first year as a teacher, Nina, a primary school teacher, said the following: 
I feel that I have gotten the most use from my ability to see my students, create relations and be patient and so on. I have focused on varying my teaching and using different didactical approaches. I have of course also used my subject knowledge.

Nonetheless, several of the novice teachers saw their initial worries confirmed during their first year as teachers. Gillian is a secondary school teacher who described how she was surprised by what the job implied beyond teaching:

Many things were different than I expected. [...] My teaching has been the least surprising part. It feels similar to when I was a substitute teacher, but now I know the children better and see them every day. That makes it easier. The biggest surprise to me was how challenging it was to be the contact teacher. [...] It takes so much time to answer emails [and] phone calls, [to have] conversations with pupils and parents, parent meetings, Christmas and summer endings [rituals to mark the end of the semester] and so on.

This is a good illustration of how ideas in teacher education and the public discourse about what teachers ought to know only partly match the complexity of the teacher's role at school in practice.

\section{Alternative Careers}

Our informants working outside the school system held a variety of jobs in the public and private sectors, with various responsibilities and statuses. They were hired as a law firm secretary, social case worker, translator, communication spokesperson, IT department leader, entrepreneur, costumer advisor, flight attendant, leader and counsellor at a school, product manager in IT, leader in an non-profit organization and salesman. They were also hired to work in a bank working with insurance, in education research, at a public institution, in a psychiatric department, in insurance and IT, in art communication and in a leading position at a recruitment agency. These persons, who had trained as teachers, had limited experience working in schools, a few years of experience as teachers or long teaching careers behind them. Only one of them had obtained additional education to work as an economist. The many alternative career paths suggest that teacher training may be an asset that is in high demand outside of the education sector.

Most of these informants continued to regard themselves as teachers with a professional identity and with a sense of belonging to the profession. When asked to reflect on their teacher training, several mentioned generic skills that have been of use as leaders, including the ability to lead a group and collaborate. In addition, several mentioned that their teacher training had been useful in terms of teaching them communication skills and enabling them to obtain new knowledge rapidly.

Trey, who works as a salesperson, described how he leads courses for colleagues at other store locations. Melanie, who is a communication spokesperson, described how she has found her training to be applicable: 
Others absolutely consider me a teacher. I am interested in people, [I] know how to listen, and I see solutions before others. Some of my current work can be regarded as teaching, and because I have a background as a teacher, I make instruction materials for my organization (Melanie).

When asked why their careers took an alternative direction, the informants gave varied reasons. One informant explained how a fixed position in a government agency was more lucrative than having a temporary position as a teacher. Another talked about having a part-time job as a student that became a long-term career possibility after graduation. He now holds a position at an employment agency as a general manager. Others left careers as teachers due to stressful work situations. Chloe now works with insurance and web design in a small firm; she left her teaching job, where she had to teach six different subjects and work 14-h days, after only 3 months:

I have always been versatile and interested in a broad spectrum of subjects.

This was also the reason why I chose teacher education. I have had many different summer jobs and part-time engagements during my studies and have always known that I wanted to try out several jobs.

She continued to describe how teacher education prepared her for professional life:

I continue to realize just how good my teacher education was. I learned to reflect on what I do and why, since reflection notes were a frequent tool in all of the subjects. I learned the value of being able to adapt and to see unique and good qualities in every pupil, in addition to good academic training, of course.

Chloe described her educational background as being especially useful due to her pedagogical competence and her ability to proofread letters sent out by the company where she works. Her employer hired her because he believes that teachers are capable of quickly learning new things. George is another informant with 3 years of experience as a teacher. He described his previous job as a teacher as demanding but rewarding. At the same time, he discovered "...that teaching is not the main aspect of the job," as he had to do a great deal of administrative work. At the time of the study, he worked with information technology and regarded his career choice as a consequence of his pedagogical training. Based on the interviews and written accounts from this group of teachers, we were able to identify several ways teachers can potentially use their educational skills in positions other than teaching, illustrating how a teaching degree gives both official admission to the profession, but more importantly, unofficial admission to other career paths. Even if these informants educated as teachers do not work as teachers, they continue to use and reproduce a professional identity as teachers in their work environment. 


\section{Discussion}

This study goes beyond a narrow focus of teacher training aimed solely at becoming a teacher and spending the rest of one's career in the education sector. As seen with a number of other occupations, including students with degrees in law, engineering, administrative and economic programs, healthcare and so on, it is not self-evident that all candidates end up in the profession and job they are trained for. The obvious question is rather how formal training may open opportunities for different kinds of career paths that are not easily governed with the current policy. Employment numbers for teachers in Norway indicate how teacher education organizations succeed in creating competences that are in high demand, even though the official public narrative devaluates the overall quality of teacher training. Teacher professionalism is created through a complex process where students' motivations for self-recruitment is one aspect (Nesje et al., 2018) and ensuring a "healthy" drop-out from those not sufficiently motivated for or suited to the profession is another (Smeplass, 2018). Furthermore, a third factor is how teacher training also emphasizes more generic skillsets, such as collaboration (Løhre et al., 2020a, 2020b), leadership (Helstad \& Møller, 2013), reflective pedagogy (Hovdenak \& Wiese, 2017), value orientations (Løhre \& Lund, 2020a; Løhre et al., 2016) and other important qualities of professional teachers in the Norwegian school system built to ensure inclusive education (Rapp \& Corral-Granados, 2021). Hence, those who complete the teacher training have also undergone socialization and internalization of teacher norms during their training, which is not possible nor desirable to regulate through national policy.

Our results show how teacher students' expectations can create institutional pressure for teacher education itself since the official program communicates an idea that teachers are fully trained for complex work in schools after obtaining their degree. Although teacher students tend to devaluate their training, when working as professional teachers, the same informants highlight personal attributes and more generic skills they believe to be important aspects of their professionality. Norwegian teachers operate in a labor market where teachers are in high demand and the official unemployment rate is normally quite low. Many novice teachers must teach subjects in which they are not formally trained. This requires a high degree of personal skills and a willingness to adjust in a complex school environment, probably equally important to the number of credit points in teaching subjects, which is the main aspect of teacher education reforms. It is central to recognize that many of the students in our study engaged in paid work as substitute teachers during their training, signaling a need for more practical training, in sharp contrast to the policy initiatives to improve teacher quality through increasing requirements for teacher competence (Ministry of Education and Research Norway, 2016a), and expanding the length and scientific aspects of the formal program (Ministry of Education and Research Norway, 2010, 2014, 2015a, 2015b). As many teachers still feel unprepared for the practical aspects of being a teacher, we believe that the one-dimensional focus on teachers' knowledge and skills in educational reforms create a widening gap between the official training and the everyday aspects of the teacher role. It is not necessarily the case that all students will become teachers in the education sector. Hence, focusing 
on the transition between teacher training and a variety of job opportunities gives a completely different outlook on teacher professionalism.

We observed a dramatic shift in terms of increased self-confidence and the ability to master the various demands associated with teaching as our informants became employees in complex organizations (Powell \& Bromley, 2015) with numerous tasks and challenges beyond the instrumental view on professional teacher skills and qualities (Meyer, 2010). It is known from organizational research that individuals as well as organizations tend to develop a number of myths to adapt and adjust to what is seen as the formal structure (Meyer \& Rowan, 1977; Smeplass, 2018). Teachers' various experiences with the profession underscore how schools officially comply with formal norms and expectations but must simultaneously adjust to the situation in terms of their resources, the institutional environment and the ecosystem in which they operate (Rapp, 2018). Our study reveals how the labor market for teachers is much more dynamic and complex than the official story of professionalism served by the government and reproduced by the teacher education organizations as they must secure their own legitimacy and maintain the monopoly they have in formally qualifying teaching staff for the educational system.

\section{Conclusion}

Images of teachers' competences as they are understood by Norwegian teacher students, teachers and employers outside of the education sector reveal structural problems with the way teacher training is being reformed. There are other skills that are associated with a formal teacher qualification. In the political debate, what are essentially seen as problems, such as the lack of highly specialized academic skills, are moderated by our informants' narratives. Both teacher students and the teachers in other sectors prove to have belief in their pedagogical values, human relations, communication and leadership skills, giving them a compound professional identity. These skills are in high demand in labor markets beyond school-based education. To what extent these findings can be observed in other countries requires more research. One plausible finding, however, is that educational systems such as the one in Norway are under substantial public pressure and therefore tend to overemphasize problems and undermine the legitimation of teacher training and teachers' professional competences to follow OECD recommendations. In light of these findings, we conclude that although the nation state has the legitimate power to define the policy for teacher education, it should investigate further what other skillsets teachers acquire during their training that makes them suitable for working in schools. In this sense, we suggest a more bottom-up approach in designing professional development, rather than a mechanic top-down construction of teacher professionalism. This could be done by recognizing students' perspectives as well as the perspectives of teacher training organizations and their staff who have longstanding experience and knowledge regarding processes of bridging pedagogical reflection, subject knowledge and didactical skillsets. 
Funding Open access funding provided by NTNU Norwegian University of Science and Technology (incl St. Olavs Hospital - Trondheim University Hospital). The authors did not receive support from any organization for the submitted work. All authors certify that they have no affiliations with or involvement in any organization or entity with any financial interest or non-financial interest in the subject matter or materials discussed in this manuscript.

\section{Declarations}

Conflict of interest The Author(s) declare(s) that there is no conflict of interest.

Ethical approval The study is registered at the Norwegian Centre for Research Data, ensuring that suitable ethical considerations have been made by the researchers. All informants are anonymized and have consented to the use of data in this study.

Open Access This article is licensed under a Creative Commons Attribution 4.0 International License, which permits use, sharing, adaptation, distribution and reproduction in any medium or format, as long as you give appropriate credit to the original author(s) and the source, provide a link to the Creative Commons licence, and indicate if changes were made. The images or other third party material in this article are included in the article's Creative Commons licence, unless indicated otherwise in a credit line to the material. If material is not included in the article's Creative Commons licence and your intended use is not permitted by statutory regulation or exceeds the permitted use, you will need to obtain permission directly from the copyright holder. To view a copy of this licence, visit http://creativecommons.org/licen ses/by/4.0/.

\section{References}

Advisory Panel for Teacher Education. (2020). Transforming Norwegian teacher education: The final report for the international advisory panel for primary and lower secondary teacher education (Report No. 3-2020). Norwegian Agency for Quality Assurance in Education. https://www.nokut. no/globalassets/nokut/rapporter/ua/2020/transforming-norwegian-teacher-education-2020.pdf

Barton, L., Barrett, E., Whitty, G., Miles, S., \& Furlong, J. (1994). Teacher education and teacher professionalism in England: Some emerging issues. British Journal of Sociology of Education, 15(4), 529-543. https://doi.org/10.1080/0142569940150406

Berger, P., \& Luckman, T. (1967). The social construction of reality: A treatise on the sociology of knowledge. Penguin Books.

Bieber, T., \& Martens, K. (2011). The OECD PISA study as a soft power in education? Lessons from Switzerland and the US. European Journal of Education, 46(1), 101-116. https://doi.org/10.1111/j. 1465-3435.2010.01462.x

Braun, V., \& Clarke, V. (2006). Using thematic analysis in psychology. Qualitative Research in Psychology, 3(2), 77-101. https://doi.org/10.1191/1478088706qp063oa

Brunsson, N. (1989). The irrational organization: Irrationality as a basis for organizational action and change. Wiley.

Brunsson, N. (2006). The organization of hypocrisy: Talk, decisions and actions in organizations. Copenhagen Business School Press.

Cochran-Smith, M. (2013). Trends and challenges in teacher education: National and international perspectives. In A. L. Østern, K. Smith, T. Ryghaug, T. Krüger, \& M. B. Postholm (Eds.), Teacher education research between national identity and global trends: NAFOL yearbook (pp. 121-138). Akademika.

DeCuir-Gunby, J. T., Marshall, P. L., \& McCulloch, A. W. (2011). Developing and using a codebook for the analysis of interview data: An example from a professional development research project. Field Methods, 23(2), 136-155. https://doi.org/10.1177/1525822X10388468

GNIST. (2016). GNIST indikatorrapport 2016. https://www.regjeringen.no/contentassets/6b3b8534bb 6749558747a51ab77d23ae/gnist-indikatorrapport-2016_.pdf 
Helstad, K., \& Møller, J. (2013). Leadership as relational work: Risks and opportunities. International Journal of Leadership in Education, 16(3), 245-262. https://doi.org/10.1080/13603124.2012. 761353

Holloway, J. (2018). Teacher evaluation as an onto-epistemic framework. British Journal of Sociology of Education, 40(2), 174-189. https://doi.org/10.1080/01425692.2018.1514291

Hovdenak, S. S., \& Wiese, E. (2017). Fronesis: Veien til profesjonell lærerutdanning? Uniped, 40(02), 170-184. https://doi.org/10.18261/issn.1893-8981-2017-02-06

Johnsen, A. (2005). What does 25 years of experience tell us about the state of performance measurement in public policy and management? Public Money and Management, 25(1), 9-17.

Köber, T., Risberg, T., \& Texmon, T. (2005). Hvor jobber førskolelarere og larere? Utdanning. https:// www.ssb.no/a/publikasjoner/pdf/sa74/kap-11.pdf

Lindblad, S., Pettersson, D., \& Popkewitz, T. S. (Eds.). (2018). Education by the numbers and the making of society: The expertise of international assessments. Routledge.

Løhre, A., \& Lund, A. B. (Eds.). (2020). Studenten skal bli larer: Kunnskap, identitet og profesjonsutvikling. Cappelen Damm Akademisk/NOASP.

Løhre, A., Etnan, R., \& Moen, E. T. (2020). Tilhørighet under klassens himmel: Lærerstudenter midtveis i profesjonsutdanningen. In A. Løhre \& A. B. Lund (Eds.), Studenten skal bli larer: Kunnskap, identitet og profesjonsutvikling (pp. 137-157). Cappelen Damm Akademisk/NOASP. https://doi. org/10.23865/noasp.98.ch7

Løhre, A., Moen, E., Etnan, R., Andersen, M., \& Uthus, M. (2016). Verdier, engasjement og tilhørighet som drivkrefter i lærerstudenters yrkesvalg og utvilking av læreridentitet. Nordisk Tidsskrift for Pedagogikk og Kritikk, 2(1), 73-87. https://doi.org/10.17585/ntpk.v2.163

Lund, E., Vik, M. G., \& Ghosh, A. (2017, August 23). Fakta: Rekruttering og frafall blant larere. Utdanningsforbundet. https:/www.utdanningsforbundet.no/nyheter/2017/fakta-rekruttering-og-frafa 1l-blant-larere/.

Meyer, H. D., \& Rowan, B. (Eds.). (2006). The new institutionalism in education. State University of New York press.

Meyer, J. W. (2010). World society, institutional theories, and the actor. Annual Review of Sociology, 36(1), 1-20. https://doi.org/10.1146/annurev.soc.012809.102506

Meyer, J. W., \& Rowan, B. (1977). Institutionalized organizations: Formal structure as myth and ceremony. American Journal of Sociology, 83(2), 340-363. https://doi.org/10.1086/226550

Ministry of Education and Research Norway. (2009). Lareren-rollen og utdanningen (Report No. 11). https://www.regjeringen.no/contentassets/dce0159e067d445aacc $82 \mathrm{c} 55 \mathrm{e} 364 \mathrm{ce} 83 / \mathrm{no} / \mathrm{pdfs} / \mathrm{stm} 20$ 0820090011000dddpdfs.pdf

Ministry of Education and Research Norway. (2010, March 21). Forskrift om rammeplan for grunnskolelarerutdanningene for 1.-7. trinn og 5.-10. trinn. https://www.regjeringen.no/no/dokum enter/rundskriv-f-05-10-forskrifter-om-ny-grun/id598615/

Ministry of Education and Research Norway. (2014). Horing - forskrifter om rammeplan for femårige grunnskolelarerutdanninger. https://www.regjeringen.no/globalassets/upload/kd/vedlegg/planer/ kd_strategiskole_web.pdf

Ministry of Education and Research Norway. (2015a, December 22). Horing - forskrifter om rammeplan for femårige grunnskolelarerutdanninger. https://www.regjeringen.no/no/dokumenter/horin g---forskrifter-om-rammeplan-for-femarige-grunnskolelarerutdanninger/id2468914/?factbox=horin gsinstanser

Ministry of Education and Research Norway. (2015b, January 28). Promotion of the status and quality of teachers. https://www.regjeringen.no/en/topics/education/innsikt/larerloftet/id2008159/

Ministry of Education and Research Norway. (2016a, June 7). Slik blir den nye laererutdanningen [Press release]. https://www.regjeringen.no/no/aktuelt/slik-blir-den-nye-larerutdanningen/id2503270/

Ministry of Education and Research Norway. (2016b, September 9). Education at a Glance 2014: Masterutdanning for larere $i$ de fleste OECD-land. https://www.regjeringen.no/no/aktuelt/Educationat-a-Glance-2014/id2000185/

Ministry of Education and Research Norway. (2017, August 9). Ni av ti nyutdannede laerere fortsetter $i$ jobben. https://www.regjeringen.no/no/aktuelt/ni-av-ti-nyutdannede-larere-fortsetter-i-jobben/id256 3568/

Ministry of Local Government and Modernization Norway. (2016, April 11). Offentlig sektor fornyes, forenkles og forbedres. https://www.regjeringen.no/no/dokumenter/offentlig-sektor-fornyes-foren kles-og-forbedres/id2482722/ 
Nav. (2021). Hovedtall om arbeidsmarkedet. https://www.nav.no/no/nav-og-samfunn/statistikk/arbeidssok ere-og-stillinger-statistikk/hovedtall-om-arbeidsmarkedet

Nesje, K., Brandmo, C., \& Berger, J. L. (2018). Motivation to become a teacher: A Norwegian validation of the factors influencing teaching choice scale. Scandinavian Journal of Educational Research, 62(6), 813-831. https://doi.org/10.1080/00313831.2017.1306804

Noordegraaf, M., \& Schinkel, W. (2011). Professionalism as symbolic capital: Materials for a Bourdieusian theory of professionalism. Comparative Sociology, 10(1), 67-96. https://doi.org/10.1163/15691 $3310 X 514083$

Nusche, D., Earl, L., Maxwell W., \& Shewbridge, C. (2011). OECD reviews of evaluation and assessment in education: Norway 2011. OECD. https://www.oecd-ilibrary.org/docserver/9789264117 006-en.pdf?expires $=1625743222 \& \mathrm{id}=\mathrm{id} \&$ accname $=$ guest $\&$ checksum $=196 \mathrm{~A} 2960350 \mathrm{D} 44082 \mathrm{E} 75$ 735743EBB585

OECD. (2012). Education at a Glance 2012. https://www.oecd.org/education/highlights.pdf

Powell, W. W., \& Bromley, P. (2015). New institutionalism in the analysis of complex organizations. In J. D. Wright (Ed.), International encyclopedia of social and behavioral sciences (2nd ed., pp. 764-769). Elsevier.

Rapp, A. (2018). Organisering av social ojämlikhet i skolan. En studie av barnskolors institutionella utformning och praktik i två nordiska kommuner. [Organizing Social Inequality in Schools. A study of Primary Schools' Institutional Design and Practice in Two Nordic Municipalities.] Doctoral Thesis. Norwegian University of Science and Technology.

Rapp, A. C., \& Corral-Granados, A. (2021). Understanding inclusive education-a theoretical contribution from system theory and the constructionist perspective. International Journal of Inclusive Education, 1-17. Advance Online Publication. https://doi.org/10.1080/13603116.2021.1946725

Roksvaag, K., \& Texmon, I. (2012). Arbeidsmarkedet for Laerere og forskolelarere fram mot år 2035 (Report No. 18). Statistics Norway. https://www.ssb.no/a/publikasjoner/pdf/rapp_201218/rapp_ 201218.pdf

Saldaña, J. (2015). The coding manual for qualitative researchers. Sage.

Smeplass, E. (2018). Konstruksjonen av den problematiske larerutdanningen: Larerutdanningen $i$ et institusjonelt og politisk landskap [The construction of the problematic teacher education. The teacher education in an institutional and political landscape] [Doctoral thesis]. Norwegian University of Science and Technology. https://ntnuopen.ntnu.no/ntnu-xmlui/bitstream/handle/11250/25711 99/Eli\%20Smeplass_PhD.pdf?sequence=1\&isAllowed=y

Statistics Norway. (2017). Pupils in primary and lower secondary school. https://www.ssb.no/en/utdan ning/statistikker/utgrs.

Statistics Norway. (2021). Employment, register-based. https://www.ssb.no/en/arbeid-og-lonn/sysselsett ing/statistikk/sysselsetting-registerbasert

Swedberg, R. (2012). 'Theorizing in sociology and social science: Turning to the context of discovery. Theory and Society, 41(1), 1-40. https://doi.org/10.1007/s11186-011-9161-5

Utdanningsforbundet. (2018). Vis tillit til profesjonen. https://www.utdanningsforbundet.no/var-politikk/ utdanningsforbundet-mener/artikler/la-larerne-vare-larere/

Publisher's Note Springer Nature remains neutral with regard to jurisdictional claims in published maps and institutional affiliations. 